\title{
Demographic data on the Little Owl (Athene noctua) in Upper-Kiskunság (Hungary) ${ }^{\times}$
}

\author{
Dániel HÁmori ${ }^{1,2^{*}}$, Dániel WinkLeR ${ }^{1} \&$ Csaba VADÁSZ ${ }^{3}$
}

Received: December 01, 2017 -Accepted: December 16, 2017

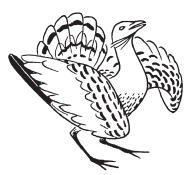

\begin{abstract}
Hámori, D., Winkler, D. \& Vadász, Cs. 2017. Demographic data on the Little Owl (Athene noctua) in Upper-Kiskunság (Hungary). - Ornis Hungarica 25(2): 11-22. DOI: 10.1515/
\end{abstract} orhu-2017-0012

${ }^{x}$ Presented at $1^{\text {st }}$ Hungarian Owl Research Conference held in Pécs on $8^{\text {th }}$ September, 2017

\begin{abstract}
This study focused on the clutch size and age-specific apparent survival rate of the Little Owl (Athene noctua) population in Upper-Kiskunság, Hungary. Between May 2005 and April 2017, 640 individuals were captured and ringed in a total of 746 capture-recapture occasions. Artificial nest boxes were installed in the study area, breeding birds and pulli were captured for ringing/recaptured in these boxes (from March to May), or at the close neighbourhood of those (max. $168 \mathrm{~m}$ ). Jolly-Seber's open population method was applied to model the survival rate. The candidate model set included models incorporating age, year-effect, and the combination of those. $\mathrm{AICc}$ value was used to compare models in a selection approach. The final model was constructed via model averaging based on the models with significant explanatory power. The average number and SD of pullus/breeding pair was $3.78 \pm 0.76$. The average apparent annual survival rate (which does not differentiate between mortality and permanent emigration) for the period between pullus stage and the time of the first breeding was estimated as $9.47 \% \pm 2.99 \% \mathrm{SE}$, whereas the annual survival rate of adults was $82.74 \% \pm 8.46 \%$ SE. The effect of sex on the survival rate of adults was not investigated due to female-biased sample, as the probability of capturing females is significantly higher in late spring months. Our experience reveals that during February and March it is possible to capture both sexes in the nest boxes, and it does not influence negatively the breeding success. Based on our results, the population of the Little Owl is stable in Upper-Kiskunság. A slight increase in estimated population size is observable even if we make no difference between mortality and permanent emigration. The high occupancy rate of the installed nest boxes reveals that nest site availability is an important limiting factor in the studied population.
\end{abstract}

Keywords: owl conservation, ringing data, age specific survival rates, Strigiformes, Hungary

Összefoglalás Vizsgálatainkkal a kuvik (Athene noctua) felső-kiskunsági populációjára jellemző átlagos fészekalj-méretet, valamint a korspecifikus, éves túlélési rátákat kívántuk meghatározni. A 2005 májusa és 2017 áprilisa közötti időszakban a Felsö-Kiskunságban 640 egyedet fogtunk meg, a visszafogásokkal együtt összesen 746 alkalommal. A madarak fémgyürüvel történő jelölése és visszafogásaik első sorban a vizsgálati területre kihelyezett mesterséges kuvikodúkban (március-június), vagy azok 168 méteren belüli környezetében történtek. A fogás-visszafogási adatokat nyílt populációs Jolly-Seber módszerrel elemeztük, az alternatív modellekben az egyedek túlélését magyarázó tényezőként a korcsoportot, az évhatást, valamint ezek kombinációját szerepeltettük. A modellek összehasonlítására az AICc értékeket használtuk, a szignifikáns magyarázóerővel bíró alternatív modellek átlagolásával állítottuk elő a végleges modellt, illetve annak paraméter értékeit. A vizsgált populációban az átlagos fészekalj-méret 3,78 $\pm 0,76 \mathrm{SD}$ fióka/fészek volt. Az átlagos, apparens túlélési ráta (amely a mortalitást és a permanens emigrációt nem különíti el) a fióka kortól a 2y korban bekövetkezö, első revírfoglalásig becsült értéke 9,47\% $\pm 2,99 \% \mathrm{SE}$, míg az 1+ korú egyedek esetében az átlagos éves apparens túlélési ráta becsült értéke $82,74 \% \pm 8,46 \% \mathrm{SE}$ volt. A túlélési ráta ivarfüggését a tojó és a hím ivarú öreg madarak költőodúban történő tavaszi megfogásának jelentősen eltérő megfogási valószínűsége miatt nem vizsgáltuk. Az elmúlt évek tapasztalatai alapján azonban leszögezhető, hogy a korai (február-márciusi) ellenőrzések során általában mind a két ivar egyedei a költöládában tartózkodnak, és a megfogás nem befolyásolja negatívan a költési sikert. Az eredmények azt támasztják alá, hogy a Felső-Kiskunságban a kuvik állomány stabil, az emigráció és a mortalitás elkülönítése nélkül is enyhe növekedő tendenciát mutat. A kihelyezett mesterséges költőládák igen ma- 
gas elfoglalási aránya azonban azt is jelzi, hogy a költésre alkalmas helyek száma fontos limitáló tényező lehet a vizsgált állomány esetében.

Kulcsszavak: bagolyvédelem, gyürüzési adatok, korspecifikus apparens túlélési ráta, Strigiformes, Magyarország

${ }^{1}$ University of Sopron, Institute of Wildlife Management and Vertebrate Zoology, 9400 Sopron, Bajcsy-Zsilinszky utca 4., Hungary, e-mail: hamoridanielkoe@gmail.com

${ }^{2}$ Hungarian Little Owl Protecting Public Benefit Association, 1082 Budapest, Szölö utca 86. 2/12., Hungary

${ }^{3}$ Kiskunság National Park, 6000 Kecskemét, Liszt Ferenc utca 19., Hungary

*corresponding author

\section{Introduction}

The populations of the Little Owl (Athene noctua) have suffered from serious decline throughout Europe during the last decades (e.g. Tucker \& Heath 1994, Génot \& Van Nieuwenhuyse 2002, Kitowski 2003, Štastný et al. 2006, Van Nieuwenhuyse et al. 2008, Šálek \& Schröpfer 2008, Thorup et al. 2010, Šálek 2014). The causes of this pattern could be originating from various sources. Changes in agronomy (intensification) and the reduction of landscape heterogeneity are factors with significant negative effect (Van Nieuwenhuyse et al. 2008, Framis et al. 2011, Šálek et al. 2016). In Central Europe, these are the extensive pastures close to settlements which form the most important breeding sites (Šálek et al. 2013, Bozó \& Csathó 2018). Due to the declining tendencies observed regarding the entire European population, research and conservation actions have been carried out in increasing number (Génot 1992, Angelici et al. 1997). Ecological demands of the Little Owl have been studied in detail (e.g. Schwarzenberg 1970, Schönn et al. 1991, Exo 1992, Van Nieuwenhuyse et al. 2001, Hardouin et al. 2006, Tomé et al. 2008, Van Nieuwenhuyse et al. 2008), but data on population dynamics and survival rate are still scarce (Exo \& Hennes 1980, Kämpfer-Lauenstein \& Lederer 1991, Letty et al. 2001, Schaub et al. 2006, Van Nieuwenhuyse et al. 2008, Thorup et al. 2010, Le Gouar et al. 2011).

The basic conditions of reaching/maintaining the stable conservation status of a specific population can be defined in different ways due to different approaches (e.g. von Haartman 1971, IUCN/SSC Criteria Review Working Group 1999).

Regarding the Hungarian Little Owl population, its spatial distribution is well-known but data is lacking on temporal changes/tendencies in population size. The Little Owl is present throughout Hungary, especially east of the river Danube (Schönn et al. 1991, Gorman 1995). The core population inhabits the Hungarian Plain, although breeding pairs can be found in hilly parts of the country, in smaller density (Gorman 1995). Typical nesting sites are the lofts of farm-houses and barns (Schmidt 1998). The estimated size of the Hungarian Little Owl population is approximately 1,500-4,000 breeding pairs, and the population tendencies are considered to be negative (Gorman 1995, Hadarics \& Zalai 2008, BirdLife International 2016, Hámori 2017a). The main threatening factors are: a) the lack of proper nesting sites as modern buildings are less sufficient for breeding (Orbán 1985), b) the significant increase in the abundance of the Beech Marten (Martes foina), which is one of the main predators of the Little Owl (Kalotás 1987), c) the indirect effect of rodenticides, d) the abandonment of pastures, e) increased mortality of juveniles by suffocation in drinking 


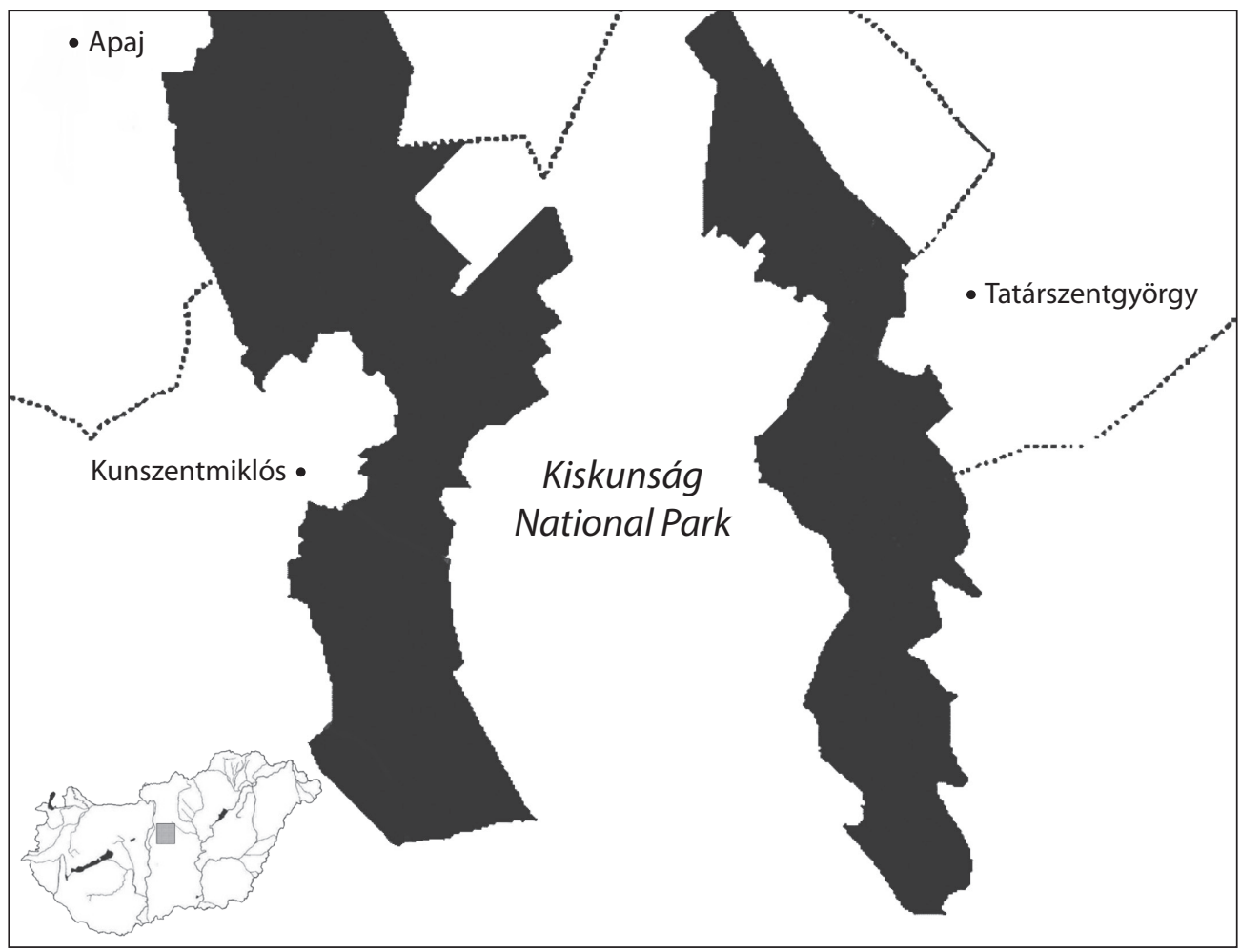

Map 1. The study area of Upper-Kiskunság 1. térkép A felső-kiskunsági kutatási terület

troughs (Génot 1991) and by f) falling in chimneys and other unescapable places (Clech 1993, Zvářal 2002). Based on dead recoveries of ringed individuals (44 specimens it total), the main causes of mortality were: a) unknown $(56.8 \%)$, b) being hit by cars $(15.9 \%)$, c) natural causes $(11.4 \%)$, d) hunting $(4.5 \%)$ and e) predation $(2.3 \%)$ (Bankovics \& Vadász 2009). No quantitative studies have yet been published on the demographic data and population trends of the Hungarian Little Owl population.

Efforts focusing on the conservation of the Little Owl involve the maintenance of sufficient feeding grounds and providing suitable nesting habitats (Van Nieuwenhuyse et al. 2008). The shortage in nesting possibilities is a common threatening factor for many species nesting in tree cavities. As the Little Owl does not build own nest, its population is usually limited by the available nesting sites (Sutherland et al. 2004), or even the decrease in available nesting sites directly leads to decreasing population size (Génot \& Van Nieuwenhuyse 2002, Thorup et al. 2010). This species is well-known for occupying artificial nest boxes. Based on this phenomenon, a number of national and international projects have been implemented to increase the probability of nesting by installing artificial nest boxes (Kirchberger 1988, Lecomte et al. 2001, Leigh 2001, Gottschalk et al. 2011). Evidently, it is of crucial importance that artificial nest boxes are installed in the neighbourhood of suitable feeding grounds characterised by the lack of natural nesting opportunities. However, in a 
long-term perspective it is regarded more plausible to maintain or to contribute to the formation of natural nesting sites for the Little Owl. Nevertheless, suitable nest boxes installed at proper places can definitely provide us the possibility of ringing pulli and adults, monitoring nesting success and also result in lower rate of nest predation (Hámori 2017b). By analysing capture-recapture data, it is possible to answer important questions (e.g. about the quality of the surrounding feeding ground), or to test hypotheses (e.g. whether the nest boxes act as ecological traps or not) (Gehlbach 1994, Mänd et al. 2005, Klein et al. 2007).

From nature conservation perspective, two of the main questions about the targeted populations are:

a) Is the investigated population stable (i.e. not showing decrease in population size)?

b) Does the investigated population act as a source population in meta-population dynamics? Considering the fundamental demographic processes, in a stable population annual mortality of adults must be compensated by the survival of young individuals entering the adult age group. The number of young individuals can also be regarded as the product of two factors: the number of fledged individuals, and their survival rate considering the period between fledging and the first breeding attempt. Therefore, to answer the first question, it is important to know the survival rates of different ages (pullus, juvenile, adult) and sex groups.

Criteria of acting as a source population are met in case of a positive internal population growth parameter $(r)$ when dispersal is possible (i.e. colonising new, suitable breeding grounds). Density is known to influence the dispersal (and the reproductive success and also the habitat use) of the Little Owl (Exo 1992, Van Nieuwenhuyse et al. 2008). As suitable breeding grounds are more-or-less isolated in space compared to the average home range of this species, dispersal ability is a key attribute that shape the distribution of the metapopulations. Pairs of Little Owls stay together throughout the whole year, without overlaps among the territories of neighbouring pairs (Exo \& Hennes 1980, Glue \& Scott 1980, Juillard 1984, Exo 1992). European studies revealed that the average distance covered by natal dispersal (i.e. the distance between the place of fledging and the place of first breeding attempt) is approximately 6.2 kilometres (Exo \& Hennes 1980, Mikkola 1983, Eick 2003). Juveniles stay close to the nest where they fledged for 35-45 days (Pedersen et al. 2013), and start the natal dispersion when they reach the age of 12-16 weeks old (Van Nieuwenhuyse et al. 2008). Natal dispersal is completed by the end of October. Most of the juveniles do not cover a distance more than $20 \mathrm{~km}$, translocations exceeding $50 \mathrm{~km}$ are rare, and only less than $3 \%$ of ringed pulli and juveniles move further than $100 \mathrm{~km}$ (Cramp 1985, Putze et al. 2009). Breeding dispersal usually covers even shorter (less than $10 \mathrm{~km}$ ) (Schönn et al. 1991, Van Nieuwenhuyse et al. 2008). Pairs of the Little Owl defend the same territory for years. Their home range covers 14-120 ha, depending on the age of individuals, population density, season and habitat characteristics (Š́lek et al. 2016). In case of mate loss, surviving adults usually choose a new mate or can move to a new territory (Sunde et al. 2009).

Within the frames of our conservation activities, artificial nest boxes have been installed in Upper-Kiskunság. With this study, we aimed to answer the following questions:

- What is the average number of pulli in artificial nest boxes in the study area? 
- What is the average apparent survival rate (which does not differentiate between mortality and permanent emigration) of individuals fledged in artificial nest boxes for the period between pullus stage and the time of the first breeding?

- What is the average apparent annual survival rate of adult individuals breeding in artificial nest boxes in the study area?

- Considering the above characteristics, can the studied population be regarded as stable (characterised with an overall positive population growth rate)?

\section{Material and methods}

The study area is located at the Hungarian Plain in Central Hungary, covering gross 70,000 hectares (centroid: N 47.068106, E 19.222133). This area is characterised by continental climate, medium level of annual precipitation $(540-670 \mathrm{~mm}$ ), hot summers and relatively cold winters (average yearly temperature: $13.3{ }^{\circ} \mathrm{C}$ ).

Formerly, this land was covered by forest steppes and large sand and alkali grasslands, while nowadays more than $60 \%$ of the area is used as arable field (Rakonczay 2001). Due to the low level of productivity, most of the grasslands are still utilised as extensive pastures, which contributed the survival of many species rare or even extinct in most of Europe. Unlike grasslands, forests of this area represent on average low conservation value, as most of those are plantations of non-native species, such as black locust (Robinia pseudoacacia), pines (Pinus sylvestris, P. nigra), hybrid poplars (Populus $\times$ euramericana) managed on short rotation cycles. In these forests there are no suitable nesting sites for the cavity breeding species, such as the Little Owl. Another issue which leads to the decrease in breeding places is that traditional buildings with open lofts (accessible for the Little Owl) slowly disappear and new buildings do not provide suitable breeding places (Hámori 2016). This is the only region in Hungary that the territories of the Little Owl are adequately mapped. Due to conservation efforts, the density of breeding pairs has increased from 0.098 pairs/100 ha (2003) to 0.161 pairs/100 ha (2016) (Hámori 2016).

Artificial nest boxes have been installed in large numbers throughout the study area to increase breeding opportunities for the Little Owl. These nest boxes follow a uniform design suggested by Haraszthy (1982), with small technical developments (Hámori 2012). The diameter of the entry hole is $85 \mathrm{~mm}$. There is a blocking plate behind the front panel against the Beech Marten (Martes foina) and to provide complete shade.

The installation of artificial nest boxes was started in 2003. Most of the nest boxes (91\%) were installed on trees at those sites, which were characterised by apparently suitable feeding grounds but with no suitable breeding places (such as old trees or buildings with accessible loft). Nest boxes were installed (or replaced, if necessary) after the fledging period, usually in August to March. This activity was started with 39 nest boxes in 2003 and to date there are 117 nest boxes are placed and monitored regularly. Nest boxes were checked three times a year: during the incubation, in the feeding periods, and after fledging. Number of eggs and pulli was recorded during the controls. The first breeding occurred in 2005 . In a given year, a nest box was regarded as occupied if eggs or pulli were found during the 
breeding period. Number of fledged juveniles refers to the number of pulli reaching the 21day old age.

Pulli and adults were individually ringed, after being captured usually inside the nest box, or within a circle with 168 -meter radius around it (covering 8.9 ha, which equals with $35 \%$ of the average home range of the Little $\mathrm{Owl}$ ), based on the findings and recommendations of literature (Exo 1987, Finck 1990, Génot \& Wilhelm 1993, Martínez \& Zuberogoitia 2004, Sunde et al. 2009, Šálek et al. 2016). During ringing, pulli were not sexed, sex of older individuals (juveniles and adults) was identified.

Encounter histories (capture-recapture data) were analysed with program MARK (Cooch $\&$ White 2017). Open population Jolly-Seber method was applied to model the age-specific apparent survival rate. The candidate model set included models incorporating age, year-effect, and the combination of those. The corrected Akaike's Information Criterion (AICc) was used for model comparison. The final model was constructed via model averaging, based on the models with significant explanatory power, according to the recommendations of Posada and Buckley (2004).

\section{Results}

While the number of installed nest boxes increased linearly, the total number of fledged pulli and the ratio of occupied nest boxes increased exponentially. The average number of fledged pulli/nest box varied between 3.77 and 7.00 during the study period (Figures $2 a, b$ ).

During the study period, 521 pulli and 119 older individuals (juveniles and adults) were ringed. In total, there were 746 capture or recapture occasions. The recapture rates of ringed pulli (21 out of 521 individuals) and older individuals (34 out of 119) were $4.03 \%$ and $28.57 \%$, respectively.

Due to the small sample size (as it was possible to identify the sex of only 19 pulli, based on following recapture data), it was not possible to incorporate a candidate model with sex groups differentiated in the final model set.

Parameters of candidate models used to estimate the apparent annual survival rates and probability of capture are presented in Table 1 .

Based on model-averaging (taking into consideration the two models with significant explanatory power (i.e. $\varphi$ (age), p (t) and $\varphi$ (age), p (age)), the average apparent annual survival rate (which does not differentiate between mortality and permanent emigration) for the period between pullus stage and the time of the first breeding was estimated as $9.47 \% \pm$ $2.99 \% \mathrm{SE}$, whereas the annual survival rate of adults was $82.74 \% \pm 8.46 \% \mathrm{SE}$. The effect of sex on the survival rate of adults was not investigated, due to female-biased sample, as the probability of capturing females is significantly higher in late spring months.

Considering the whole study period, the average number and SD of pullus/breeding pair was $3.78 \pm 0.76$.

Altogether, taking into consideration all the above parameters, the population growth rate was estimated to be slightly positive $(r=0.006)$ 

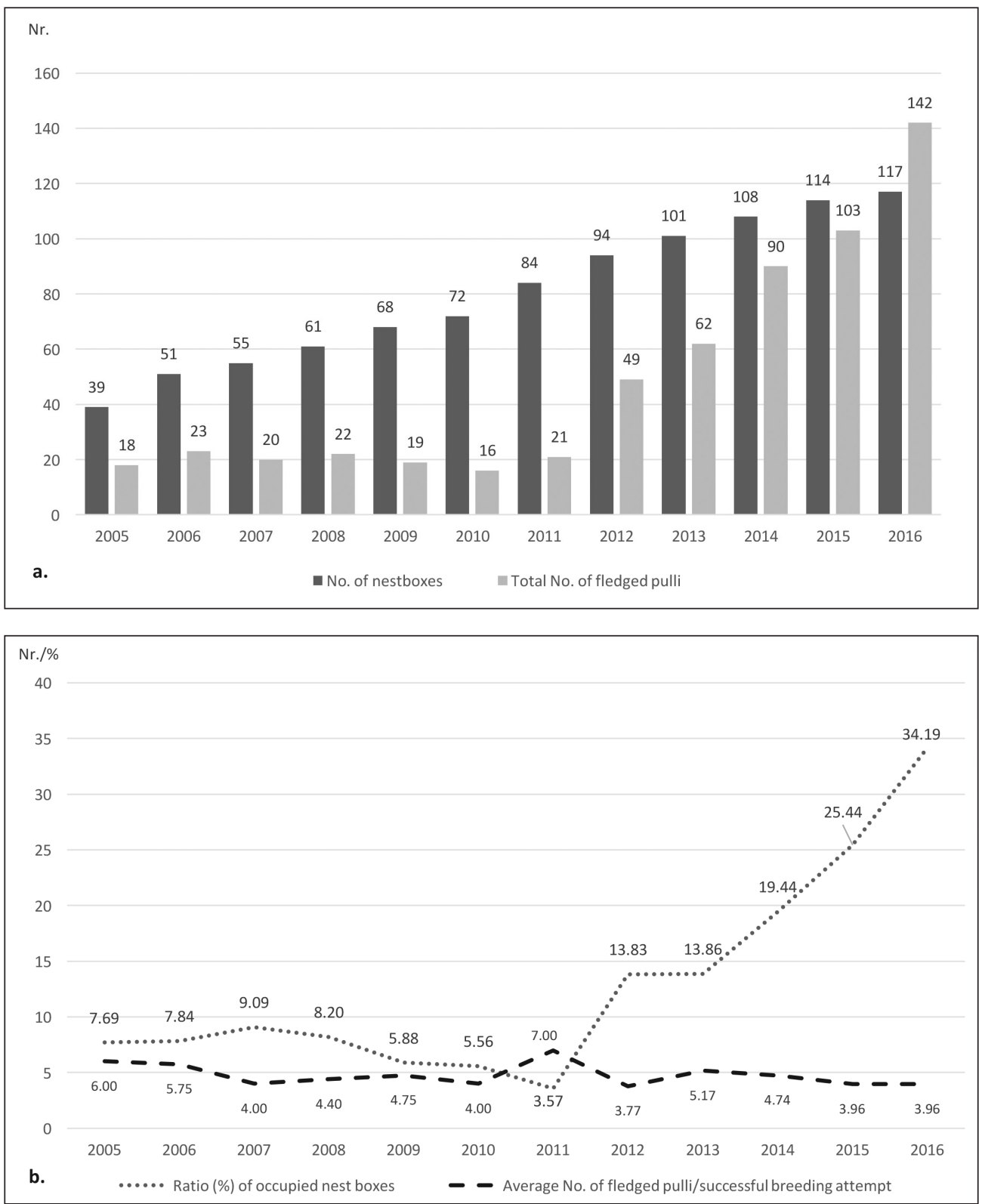

Figure 2. Number of installed nest boxes and total number of fledged pulli (a); Ratio of occupied nest boxes and the average number of fledged pulli/successful breeding attempt (b) in UpperKiskunság, between 2005 and 2016

2. ábra A kihelyezett mesterséges odúk és a kirepült fiókák száma (a); A mesterséges odúk foglalási aránya, valamint a sikeresen kirepült fiókák számának átlaga (b) a Felső-Kiskunságban (2005-2016) 
Table 1. Parameters of candidate models used to estimate the apparent annual survival rates and probability of capture. $\varphi$ and $p$ denote the survival rate and the probability of capture, respectively. In brackets following the above parameters, age and $t$ indicate the age-dependence and the year-effect of the specific parameter, respectively, whereas $a g e^{*} t$ indicates that there is age-dependency and year-effect in the case of the specific parameter, according to the candidate model. A dot in brackets (.) indicates that there is neither age-dependency nor year-effect regarding the specific parameter. " indicates models with significant explanatory power. No. of parameters refers to the number of dependant variables estimated by the specific candidate model

1. táblázat $A z$ éves túlélési ráta és a visszafogás valószínúségét leíró modellek paraméterei. $\varphi$ és $p$ a túlélési rátát, illetve a visszafogás valószínúségét jelölik. Zárójelben az alábbi paraméterek: age és $t$ az adott paraméter kor-, ill. évhatás függését jelölik, míg az $a g e^{*} t$ jelölés az évhatás és a korfüggés együttes fennállását jelenti az alternatív modell szerint. A zárójelben lévő pont (.) azt jelenti, hogy az adott paraméter a korcsoporttól és évhatástól független. ${ }^{*}$ szimbólum: a modell szignifikáns magyarázóerővel bír

\begin{tabular}{|l|c|c|c|c|}
\hline \multicolumn{1}{|c|}{ Candidate model } & AICc & DAICc & AICc weight & No. of parameters \\
\hline$\varphi($ age $), p(t)$ & 268.55 & 0.00 & $0.8555^{\#}$ & 14 \\
\hline$\varphi($ age),p(age) & 272.12 & 3.57 & $0.1445^{\#}$ & 4 \\
\hline$\varphi($ age*t),p(age) & 283.81 & 15.25 & 0 & 21 \\
\hline$\varphi($ age),p(age*t) & 285.03 & 16.47 & 0 & 25 \\
\hline$\varphi(),. p(t)$ & 288.40 & 19.85 & 0 & 13 \\
\hline$\varphi(),. p()$. & 292.14 & 23.58 & 0 & 2 \\
\hline$\varphi(t), p(t)$ & 295.39 & 26.83 & 0 & 13 \\
\hline$\varphi(t), p(t)$ & 296.97 & 28.41 & 0 & 20 \\
\hline
\end{tabular}

\section{Discussion}

Our results revealed that the Little Owl population in Upper-Kiskunság is heavily limited by the available nesting sites, which is supported by the fact that by the end of the study period $34.19 \%$ of the installed artificial nest boxes have been occupied by breeding pairs. It is absolutely in line with the findings of other European studies (Génot \& Van Nieuwenhuyse 2002, Sutherland et al. 2004, Thorup et al. 2010).

As nest boxes were installed at places characterised by apparently suitable feeding grounds and with no suitable breeding places (therefore with no breeding pairs), we believe that this phenomenon (i.e. that nest boxes have been occupied) contributes to an overall increase in the number of breeding pairs in the study area. Accordingly, installing nest boxes in regions with limited breeding possibility can contribute to successful conservation of the Little Owl (Kirchberger 1988, Lecomte et al. 2001, Leigh 2001, Gottschalk et al. 2011).

Hypothetically, it could happen that pairs having bred at other sites/occupied other territories performed a territory shift to occupy a new one. Due to the high level of breeding site fidelity ( $c f$. Schönn et al. 1991, Van Nieuwenhuyse et al. 2008), we do not consider 
long-range breeding dispersal as a probable reason of high level of occupancy of nest boxes. Unfortunately, as Little Owls nests in traditional nesting sites (such as lofts) are seldom ringed, there is no possibility to test this hypothesis.

Besides the rate of occupancy, it is very important to test whether artificial nest boxes act as ecological traps (e.g. by attracting breeding pairs but resulting in low level of breeding success). Our results highlight that the annual survival rate of adults breeding in nest boxes is very high $(82.74 \%)$, which proves that nest boxes are safe breeding structures. Due to high density of the Beech Marten population, which is the most common predator of the Little Owl (Kalotás 1987), predator-safe breeding sites form the basis of a viable owl population. Furthermore, as the calculated population growth rate was slightly positive (0.006), the population of the Little Owl can be considered as stable in Upper-Kiskunság. As a slight increase in estimated population size is observable even if we can make no difference between mortality and permanent emigration due to the study design (no effort was put to capture and to ring Little Owls breeding at other locations), we can hypothesise that the sub-population nesting in nest boxes can be considered as a kind of source-population, as juveniles fledged from nest boxes can occupy new territories. The exponential character of rate of occupied nest boxes (see Figure $2 b$ ) may support this hypothesis.

As an additional finding, we realised that during February and March it is possible to capture both sexes in the nest boxes, and it does not influence negatively the breeding success.

In Hungary, the core population of the Little Owl is located in the Hungarian Plain, especially east of the river Danube (Schönn et al. 1991, Gorman 1995). Our study area is part of the Hungarian Plain, with large, extensively grazed grasslands. Therefore, we hypothesise that loss of suitable feeding habitats is not a significant threatening factor considering the local Little Owl population, contrary to other regions throughout Europe and even in Hungary (Gorman 1995, Hadarics \& Zalai 2008, Van Nieuwenhuyse et al. 2008, Framis et al. 2011, BirdLife International 2016, Śálek et al. 2016, Hámori 2017a). Accordingly, it is the amount of available nesting sites which limits the population, forming a serious obstacle towards further population growth. Due to positive changes in the landscape-structure (the extent of pasture has significantly increased during the last two decades) and in forestry practices (old trees with cavity are not removed from forests and roadside groves), the local conditions are preferable for Little Owls in the foreseeable future.

\section{Acknowledgements}

We are deeply indebted to the members of the Hungarian Little Owl Protecting Public Benefit Association and our colleagues at Kiskunság National Park for their help in the field work. Supported by the ÚNKP-17-3-I New National Excellence Program of the Ministry of Human Capacities. 


\section{References}

Angelici, F. M., Latella, L., Luiselli, L. \& Riga, F. 1997. The summer diet of the Little Owl (Athene noctua) on the Island of Astipalaia (Dodecanese, Greece). - Journal of Raptor Research 3: 280-282.

Bankovics, A. \& Vadász, A. 2009. Kuvik [The Little Owl]. - In: Csörgő, T., Karcza, Zs., Halmos, G., Magyar, G., Gyurácz, J., Szép, T., Bankovics, A., Schmidt, A. \& Schmidt, E. (eds.) 2009. Magyar madárvonulási atlasz [Hungarian Bird Migration Atlas]. - Kossuth Kiadó Zrt., Budapest, pp. 361-362. (in Hungarian with English Summary)

BirdLife International 2016. Athene noctua. - The IUCN Red List of Threatened Species 2016: e. T22689328A86869477. - Downloaded on 21 March 2017.

Bozó, L. \& Csathó, A. I. 2017. The status and population changes of the Little Owl (Athene noctua) in the south of Békés county (Hungary). - Ornis Hungarica 26(2): 23-33. DOI: 10.1515/orhu-2017-0013

Clech, D. 1993. La Chouette chevêche Athene noctua en Bretagne [The Little Owl Athene noctua in Bretagne]. - ArVran 4: 5-34. (in French)

Cooch, E. G. \& White, G. C. 2017. Program MARK - a gentle introduction (software manual). http://www.phidot.org/software/mark/docs/book/pdf/mark book.zip

Cramp, S. (ed.) 1985. Handbook of the Birds of Europe, the Middle East and North Africa. The Birds of the Western Palearctic, Vol. 4. - Oxford University Press, Oxford

Eick, M. 2003. Habitatnutzung und Dismigration des Steinkauzes Athene noctua [Habitat use and dismigration of Little Owl]. - Master's thesis, Universitat Hohenheim (in German)

Exo, K. M. 1987. Das Territorialverhalten des Steinkauzes (Athene noctua) - eine verhaltensökologische Studie mit Hilfe der Telemetrie [The territorial behavior of Little Owl (Athene noctua) - a behavioral ecological study using telemetry]. - Dissertation, University of Köln (in German)

Exo, K. M. 1992. Population ecology of Little Owls Athene noctua in Central Europe: a review. - In: Galbraith, C. A., Taylor, I. R. \& Percival, S. (eds.) The Ecology and Conservation of European Owls. - Joint Nature Conservation Committee, UK Nature Conservation, No. 5. Petersborough, pp. 64-75.

Exo, K. M. \& R. Hennes. 1980. Beitrag zur Populationsökologie des Steinkauzes (Athene noctua) [Contribution to the population ecology of Little Owl (Athene noctua)]. - Vogelwelt 99: 137-141. (in German)

Finck, P. 1990. Seasonal variation of territory size with the Little Owl (Athene noctua). - Oecologia 83(1): 68-75.

Framis, H., Holroyd, G. L. \& Mañosa, S. 2011. Home range and habitat use of Little Owl (Athene noctua) in an agricultural landscape in coastal Catalonia, Spain. - Animal Biodiversity and Conservation 34(2): 369-378.

Gehlbach, F. R. 1994. Nest-box versus natural-cavity nests of the Eastern Screech-owl. - an exploratory study. Journal of Raptor Research 28: 154-157.

Génot, J. C. 1991. Mortalité de la Chouette chevêche, Athene noctua, en France [Mortality of Little Owls Athene noctua, in France]. - In: Juillard, M., Bassin, P. \& Baudvin, H. (eds.) Rapaces Nocturnes Actes du 30e colloque interrégional d'ornithologie Porrentruy (Suisse).- Nos Oiseaux pp. 139-148. (in French)

Génot, J. C. 1992. Biologie de reproduction de la Chouette chevêche Athene noctua, en France [Mortality of Little Owls Athene noctua, in France]. - L'Oiseau et R. F. O. 62: 309-319. (in French)

Génot, J. C. \& Wilhelm, J. L. 1993. Occupation et utilisation de l'espace par la chouette chevêche Athene noctua, en bordure des Vosges du Nord [Habitat occupancy and habitat use of Little Owl (Athene noctua) at the border of Northern Vosges]. - Alauda 1(3): 181-194. (in French)

Génot, J. C. \& Van Nieuwenhuyse, D. 2002. Little Owl Athene noctua. - Birds of Western Palearctic Update 4: 35-63.

Glue, D. \& Scott, D. 1980. Breeding biology of the Little Owl. - British Birds 73: 167-180.

Gorman, G. 1995. The status of owls (Strigiformes) in Hungary. - Buteo 7: 95-108.

Gottschalk, T. K., Ekschmitt, K. \& Wolters, V. 2011. Efficient placement of nest boxes for the Little Owl (Athene noctua). - Journal of Raptor Research 45(1): 1-14. DOI: 10.3356/JRR-09-11.1

Hadarics, T. \& Zalai, T. 2008. Magyarország madarainak névjegyzéke - Nomenclator Avium Hungariae - An annotated list of the birds of Hungary. - MME, Budapest, p. 148 (in Hungarian with English Summary)

Hámori, D. 2012. Kuvikodú-telepítés szempontjai alföldi területeken [Criteria for installing nest boxes for Little Owl (Athene noctua) in the lowland areas]. - Heliaca 10: 61-63. (in Hungarian with English Summary)

Hámori, D. 2016. Antropogén fészkelö-helyekre kényszerült kuvik Athene noctua (Scopoli, 1769) konzervációbiológiai lehetőségei a Felső-Kiskunságban [Conservation biological aspects of the Little Owl (Athene noctua, Scopoli, 1769) adapted to anthropogenic nesting environment, Upper-Kiskunság, Hungary]. - Erdészettudományi Közlemények 6(2): 175-187. DOI: 10.17164/EK.2016.014 (in Hungarian) 
Hámori, D. 2017a Kuvikvédelem egy közép-magyarországi mezőgazdasági területen: költési adatok és a mesterséges fészekodvak paramétereinek összefüggései [Little Owl conservation in farmland areas of Central-Hungary: relationships between the nesting data and nestbox parameters]. - Magyar Apróvad Közlemények 13: 187-199. DOI: 10.17243/mavk.2017.187 (in Hungarian)

Hámori, D. 2017b Kuvik [Little Owl]. - In: Hámori, D. \& Csörgő, T. (eds.) 2017. Magyarországon előforduló bagolyfajok határozása és gyakorlati természetvédelme [Determination and conservation of owls occurring in Hungary]. - Herman Ottó Intézet, Budapest, pp. 62-69. (in Hungarian)

Haraszthy, L. 1982. Kuvik-odú készítése [Making of nest boxes for Little Owl]. - Madártani Tájékoztató, okt.dec.: 259-262. (in Hungarian)

Hardouin, L. A., Tabel, P. \& Bretagnolle, V. 2006. Neighbour-stranger discrimination in the Little Owl, Athene noctua. - Animal Behaviour 72: 105-112. DOI: 10.1016/j.anbehav.2005.09.020

IUCN/SSC Criteria Review Working Group. 1999. IUCN Red List Criteria review provisional report: draft of the proposed changes and recommendations. - Species 31-32: 43-57.

Juillard, M. 1984. La chouette chevêche [The Little Owl]. - Nos Oiseaux, Prangins (in French)

Kalotás, Zs. 1987. Adalékok a menyétféle ragadozók fészekalj pusztító tevékenységéhez és károsításaik megelőzéséhez [Notes on mustelid nest predation and its prevention]. - Madártani Tájékoztató, jan.-jún.: 13-16. (in Hungarian)

Kämpfer-Lauenstein, A. \& Lederer, W. 1991. Zur Dismigration und Populationsdynamik des Steinkauzes (Athene noctua) in Mittelwestfalen [On the dismigration and population dynamics of the Little Owl (Athene noctua) in Central Westphalia]. - Populationsökologie Greifvogelund Eulenarten 2: 479-491. (in German)

Kirchberger, K. 1988. Artenschutzmöglichkeiten beim Steinkauz und Schwarzmilan [Species protection options for Little Owl and Black Kite]. - Vogelschutz im Österreich 2: 52-55. (in German)

Kitowski, I. 2003. The monitoring of Little Owl Athene noctua in Chelm (SE Poland) in 1998-2000. - Ornis Hungarica 12-13: 279-283.

Klein, Á., Nagy, T., Csörgő, T. \& Mátics, R. 2007. Exterior nest-boxes may negatively affect Barn Owl Tyto alba survival: an ecological trap. - Bird Conservation International 17(3): 273-281. DOI: 10.1017/ S0959270907000792

Le Gouar, P. J., Schekkerman, H., Van der Jeugd, H. P., Boele, A., Van Harxen, R., Fuchs, P., Stroeken, P. \& Van Noordwijk, A. J. 2011. Long-term trends in survival of a declining population: the case of the Little Owl (Athene noctua) in the Netherlands. - Oecologia 166: 369-379. DOI: 10.1007/s00442-010-1868-x

Lecomte, P., Lapios, J-M. \& Génot, J-C. 2001. Plan de restaruation des populations de Chevêches d'Athéna en France [Population restoration plan for Little Owl in France]. - In: Génot, J. C., Lapios, J.-M., Lecomte, P. \& Leigh, R. S. (eds.) Chouette chevêche et territoires. Actes du Colloque International de Champ-sur-Marne, November 25-26, 2000. ILOWG. - Ciconia 25: 159-171. (in French)

Leigh, R. 2001. The breeding dynamics of Little Owls (Athene noctua) in North West England. - In: Génot, J. C., Lapios, J-M., Lecomte, P. \& Leigh, R. S. (eds.) Chouette chevêche et territoires. Actes du Colloque International de Champ-sur-Marne, November 25-26, 2000. ILOWG. - Ciconia 25: 67-76.

Letty, J., Génot, J-C. \& Sarrazin, F. 2001. Viabilité de la population de Chevêche d'Athéna Athene noctua dans le Parc Naturel Régional des Vosges du Nord [Analysis of population viability of Little Owl (Athene noctua) in the Northern Vosges natural park (north-eastern France)]. - Alauda 69(3): 359-372. (in French)

Mänd, R., Tilgar, V., Lõhmus, A. \& Leivits, A. 2005. Providing nest boxes for hole-nesting birds - does habitat matter? - Biodiversity Conservation 14: 1823-1840. DOI: 10.1007/s10531-004-1039-7

Martínez, J. A. \& Zuberogoitia, I. 2004. Habitat preferences for Long-eared Owls Asio otus and Little Owls Athene noctua in semi-arid environments at three spatial scales. - Bird Study 51(2): 163-169. DOI: $10.1080 / 00063650409461348$

Mikkola, H. 1983. Owls of Europe. - T \& AD Poyser, Staffordshire

Orbán, Z. 1985. Szalmakazlakban fészkelö kuvikok (Athene noctua) [Little Owls breeding in straw stacks]. Madártani Tájékoztató, júl.-dec.: p. 51. (in Hungarian)

Pedersen, D., Thorup, K., Sunde, P., Jacobsen, L. B. \& Rahbek, C. 2013. Post-fledging behaviour of juveniles in the Little Owl (Athene noctua). - Ornis Fennica 90(1): 117-128.

Posada, D. \& Buckley, T. R. 2004. Model selection and model averaging in phylogenetics: advantages of Akaike information criterion and Bayesian approaches over likelihood ratio tests. - Systematic Biology 53(5): 793-808.

Putze, M., Eisenberg. A., Hanft. M., Moser. F. \& Langgemach, T. 2009. Telemetrie von Steinkäuzen (Athene noctua) im Havelland 2006/2007 [Telemetry of Little Owls (Athene noctua) in Havelland]. - Otis 17: 59-68. 
Rakonczay, Z. (ed.) 2001. A Kiskunságtól Bácsalmásig (A Kiskunság természeti értékei) [From Kiskunság to Bácsalmás (Natural values of Kiskunság)]. - Mezőgazda Kiadó, Budapest

Šálek, M. 2014. Dlouhodobý pokles početnosti sýčka obecného (Athene noctua) v jádrové oblasti jeho rozšíření v Čechách [Long-term population decline of the Little Owl (Athene nocuta) in a core area of its distribution in Bohemia]. - Sylvia 50: 2-11. (in Czech)

Šálek, M. \& Schröpfer, L. 2008. Population decline of the Little Owl (Athene noctua Scop.) in the Czech Republic. - Polish Journal of Ecology 56: 527-534.

Šálek, M., Chrenkova, M. \& Kipson, M. 2013. High population density of Little Owl (Athene noctua) in Hortobágy National Park, Hungary, Central Europe. - Polish Journal of Ecology 61(1): 165-169.

Šálek, M., Chrenková, M., Dobrý, M., Kipson M., Grill, S. \& Václav, R. 2016. Scale-dependent habitat associations of a rapidly declining farmland predator, the Little Owl Athene noctua, in contrasting agricultural landscapes. - Agriculture, Ecosystems \& Environment 224: 56-66. DOI: 10.1016/j.agee.2016.03.031

Schaub, M., Ullrich, B., Knötzsch, G., Albrecht, P. \& Meisser, C. 2006. Local population dynamics and the impact of scale and isolation: a study on different Little Owl populations. - Oikos 115(3): 389-400. DOI: 10.1111/j.2006.0030-1299.15374.x

Schmidt, E. 1998. Kuvik [Little Owl]. - In: Haraszthy, L. (ed.) Magyarország madarai [Birds of Hungary]. Mezőgazda Kiadó, Budapest, pp. 218-219. (in Hungarian)

Schönn, S., Scherzinger, W., Exo, K. M. \& Ille, R. 1991. Der Steinkauz [Little Owl]. - Die Neue Brehm-Bücherei, Vol. 606. - A. Ziemsen Verlag, Wittenberg Lutherstadt, Germany (in German)

Schwarzenberg, L. 1970. Hilfe unserem Steinkauz [Help our Little Owls]. - DBV Jahresheft 20-23. (in German)

Štastný, K., Bejček, V. \& Hudec, K. 2006. Atlas hnízdního rozšíření ptáků v České Republice 2001-2003 [Atlas of the breeding birds in the Czech Republic, 2001-2003]. - Aventinum 2006, Praha, pp. 90-92. (in Czech)

Sunde, P., Thorup, K., Jacobsen, L. B., Holsegard-Rasmussen, M. H., Ottessen, N., Svenné, S. \& Rahbek, C. 2009. Spatial behaviour of Little Owls (Athene noctua) in a declining low-density population in Denmark. Journal of Ornithology 150(3): 537-548. DOI: 10.1007/s10336-009-0378-2

Sutherland, W. J., Newton, I. \& Green, R. E. 2004. Bird ecology and conservation. - Oxford University Press, New York

Thorup, K., Sunde, P., Jacobsen, L. B. \& Rahbek, C. 2010. Breeding season food limitation drives population decline of Little Owl Athene noctua in Denmark. - Ibis 152: 803-814. DOI: 10.1111/j.1474-919X.2010.01046.x

Tomé, R., Catry, P., Bloise, C. \& Korpimäki, E. 2008. Breeding density and success, and diet composition of Little Owls Athene noctua in steppe-like habitats in Portugal. - Ornis Fennica 85: 22-32.

Tucker, G. M. \& Heath, M. F. 1994. Birds in Europe: their conservation status. - BirdLife International, Cambridge

Van Nieuwenhuyse, D., Leysen, M. \& Steenhoudt, K. 2001. Analysis and spatial prediction of Little Owl Athene noctua distribution in relation to its living environment in Flanders (northern Belgium). - Oriolus 67(2-3): $32-51$.

Van Nieuwenhuyse, D., Genot, J. \& Johnson, D. 2008. The Little Owl: Conservation, Ecology and Behavior of Athene noctua. - Cambridge, New York, Cambridge University Press

von Haartman, L. 1971. Population dynamics. - In: Farner, D. S. \& J. R. King (eds.) Avian biology. Vol. 1. - Academic Press, New York, USA. pp. 391-459.

Zvářal, K. 2002. Can ,architectural traps" be the cause of the critical decrease of Little Owl (Athene noctua)? Crex 18: 94-99. 